\title{
English Meeting Club: Students' Perception and Their Speaking Skill
}

\author{
Hijrah $^{(1)}$, Nurul Hikmah Umar ${ }^{(2)}$ \\ Universitas Muhammadiyah Makassar, Indonesia \\ E-mail: ${ }^{(1)}$ hijrah@unismuh.ac.id, ${ }^{(2)}$ hikmahumar99@gmail.com
}

Received: 9 October 2021; Revised: 10 November 2021; Accepted: 13 November 2021

\begin{abstract}
This study aims to find out students' perception of English meeting club to support their speaking skill. English meeting club was a club or group of humans with common ambitions or interests in English. This study focused on the students' perception of English meeting club to support their speaking skill. The subject of this study are 10 students of English department as participants. This study used a qualitative method, this study used interview as research instrument. The result of interviews, the majority of the students had positive perception about joined in English club. The student absolutely believes if English club could support them to speak English fluently. The student also had a perception through an English meeting club as a media to develop skills particularly in speaking, it could be one of the alternatives for those who need to learn and practice more about how to speak English well and it can also enhance their ability to speak English fluently.
\end{abstract}

Keywords: Students’ perception, English meeting club, Speaking skill.

\section{Introduction}

Speaking has become such a part of our daily life that individuals take it for granted. Speaking is an activity for the exchange of ideas or information, and it is an activity for efficient communication. Speaking is also a type of practicing language specifically, which can help students who are still fluent in communication to have good communication skills. It is important to the students to learn speaking correctly, to master speaking skill students should be educated to use English in oral communication. Speaking is one of the importance skill because speaking is an action to convey information or to express one's own thoughts and feeling in the spoken language. It is one of the skills English needs to be learn to enhance the communication between the students and other people.

In addition, most of the students still seem to be difficult to speak English fluently, the students do not know how to interpret various transactional and interaction signals in spe- cific situations. There are some problems causes by a various factor, including hesitation, awkwardness, lack of confidence, fear to make a mistakes. That is all problems can be making oral errors other than students, show poor speaking ability and lack of peers or social competence.

Nowadays there are some effective ways that can support students to enhance their speaking skill, one of them is joining English meeting club. According to Yuliandasari (2015) the benefits of joining the English club is that students will be able to participate. Various activities based on the objectives of the club, students will have the opportunity to take part in the national and international competitions in English, Students will be able to develop their listening and speaking skill. Formal and informal situations, and last but not least, students will have a chance to go aboard and learn about different cultures and to achieve the benefits required to be able to use English as a language of commu- 
nication.

The researcher conducted to research on students' perception in practicing speaking English by the tittle "Students' Perception of English Meeting Club to Support Their Speaking Skill". Based on the background illustrated above the researcher formulated the problem statement / research problem as follow: what are students' perception of English meeting club to support their speaking skill? Based on the research problem / research questions above, the objective of the research is to find out students' perception of English meeting club to support their speaking skill.

This study expects to be useful information for many people in learning process, such as this research is expected to contribute theoretically and practically in the development of English teaching. The researcher also expected to give the students way to learn English and make them confident in speak English. This research could be used as a reference for other researcher who interested in conducting research which has the same topic. This study focused on the students' perception in terms of English meeting club to support their speaking skill.

\section{Materials and Method}

This study used descriptive qualitative method as a research design. Qualitative research attempts to explore and improving a problem from a comprehensive phenomenon (Cresswell, 2012) and it helps the researcher to explore the students' speaking skill Creswell (2012) stated that a qualitative research approach is a way of gathering data based on small words number of people to get the opinions of the participants and the researcher submitted qualitative as a research approach to know the views of the participants on the data needed based on actual facts.

The participants of this research was the student in English department who had joined and it consisted of 10 students, the participants are selective by using purposive sampling technique. Purposive used because there are participant criterions, such as the chosen participants should be joined English meeting club.

To found out the students' perception of
English meeting club, this research used instrument to gathering the data. Research instrument is a tool that is used by the research to collect the data. The use of instrument depends on the data which are needed by the researcher, and it related to the research problem. In this research, the researcher used interview as research instrument. The interview was structured interview and the interview was online mode through WhatsApp online messenger and using Google form as media because the pandemic Covid-19.

In collecting the data, the researcher presented some procedures such as the researcher will ask for permission to the participant via online chat. The researcher explains the objective of the interview. The researcher gives the link of google form to the participant that has some questions as interview that related to English meeting club.

After collecting the data, the researcher classifies the data through google form. Classifying data is a grouping of data into more detail than previous data. The researcher transcribes the results, summarizes the findings and draw some conclusions from such findings. The researcher can conclude data analysis. Besides that, researchers also make implementations and suggestions based on data information.

\section{Results and Discussion Results}

Results should be clear and concise. To produce the data of this research students related to interviews through online mode by using google form. The aim of this research is to find out students' perception of English meeting club to support their speaking skill. The researcher took students from English department who had joined English meeting club. The data from the interview list are based on the rules in collecting data and to find out students' perception of English meeting club. In order to get the actual data from the students to find out student's perception of English meeting club. The researcher had asked the students by interviews. In order to get the actual data from the students to find out student's perception of English meeting club. The researcher had asked the students by interviews. The findings of each interview are listed out in 
description below:

\section{How you defined English meeting club in general?}

Based on the interview given to the students by the researcher with the question above, majority of the student defined that English meeting club is a place to learn English in informal setting with other people. Some of the students assumed that English meeting club was a club that can increase the students' ability in learning English.

\section{What are the benefits do you get after joining English meeting club?}

Dependent on the interview that the researcher gave to the students with the question above Most of the students stated that joining English meeting club can make them feel more confidence in speaking English like public speaking and the English club plays a significant social role. An English club might be a place to meet new people and make new friends. Not only in speaking aspects, join English meeting club could improve vocabulary mastery and the other side, join English meeting club had a lot of fun and enjoyable in learning English.

\section{Does English meeting club can help you speak English well? Explain your reasons!}

Focused on the researcher's interview given to the students with the question above, most of the students stated that English meet club could help the student to speak English well. Most of the students claimed that in English meeting club they trained how to speak English well and the mentors help them to improve their speaking skill. Some of the students stated that they enjoyable while speaking because did not feel awkward and feel more comfortable.

\section{Do you get improvement in speaking ability after joining English meeting club? What's your improvement?}

Depend on the interview given to the students by the researcher with the question above, the researcher inferred that at the English meeting club, they improved when speaking English, no longer fillers, could pronounce the words appropriately, speak well throughout pronunciation, speak correctly and feel confident in speaking. In addition to enhancing one's English communication abilities, language skills are important for self-improvement as well as for engagement in various social spheres.

\section{After joining the English meeting club, are you} motivated to speak English continuously?

Based on the interview given to the students by the researcher with the question above, majority of the students had an opinion that the English meeting club had a big role to make him motivated in speaking English continually. Based on the all students' statements above, the researcher concluded that the students claimed they after joined English meeting club, they motivated to speak English continually, felt more enthusiastic while speaking English and English club could improve their ability.

What do you think about practicing speaking in regular class or English meeting club. Which one do you prefer?

Focused on the interview given to the students by the researcher with the question above, most of the student stated that they prefer learned English in English meeting club than in formal learning because they felt more confident in speaking, more expressive, got a lot of improvement in speaking English. Not just learn about speaking itself, in English meeting club the students also learned about the culture of speaking English. Many learners find them more exciting than normal classes in English. In more real-life they also let learners practice English.

\section{Do you believe that if English meeting club can support you to speak English fluently? Why?}

Focused on the researchers' interview given to the students with the question above, majority of the students had a perception the students believed that English meeting club could support their speaking skill, developed their English skill because this activity can support our ability in speaking English more fluently. While one students of them believed if English meeting club not only supported one to her to develop her speaking skill, they stated there also the other way to learn English especially speaking such learned through internet. 


\section{Discussion}

Refers to the perception of all students that the researcher obtained from the online mode interview the researcher found that the English meeting club is a place for learning English in an informal environment with other people. Some students thought that the English meeting club was a club that could improve students' interest in learning English. Joined the English meeting club could help them feel more confident in speaking English like a native speaker and not only in speaking aspects, joining the English meeting club could develop vocabulary skills, while on the other words, joined the English meeting club had a lot of fun as well as enjoyable in learning English.

According to the results of interview, the researcher took a conclusion from 10 students as participants and most of the students agree that English meeting club support their speaking skill and could improve students' interest in learning English. Activities in the English club often encourage students to be more inspired and enthusiastic to practice speaking English with their friends and to exchange knowledge and information. The English Club is therefore an important platform for developing students' speaking and joined the English meeting club had a lot of fun as well as enjoyable in learning English.

\section{Conclusion}

This research focused on the students' perception toward English meeting club to support their speaking skill. Depends on the data analysis in result and discussion, it can be inferred that majority of students had a positive perception of the English meeting club. The student absolutely believes if English club could support them to speak English fluently. The student also had a perception through an English meeting club as a media to develod skills particularly in speaking, it could be one of the alternatives for those who need to learn and practice more about how to speak English well and it can also enhance their ability to speak English fluently. The English club often encourages students to be more empowered and excited to practice speaking English with their friends and to share new knowledge and information. Stu- dents obtain new vocabulary and self-confidence after joining the English club activities; communicate about something related to our ordinary activities, see or see their friends while they speak English and though about the normal stuff about how to speak well in front of the public.

\section{References}

Adhwani, H. (2018). Developing a set of public speaking learning material for the English club of Indonesian high school. English Language Teaching Journal, 7(1), 1-6.

Agustina, D. (2019). Students' perception of the Jigsaw technique implementation in learning speaking at the first-grade of SMA N 7 Bandar Lampung.

Allen, J. F. (2012). A set of speaking material based on communicative language teahing for the extracurricular English club of SMP Kanisius Pakem Yogyakarta (Doctoral dissertation, Sanata Dharma University).

Armita, Y. (2019). Students' Perception Toward English Club Extracurricular Activities in Practicing Speaking at SMA N 02 Kaur, Bengkulu (Doctoral dissertation, IAIN Bengkulu).

Elnadeef, E. A. E., \& Abdala, A. H. E. H. (2019). The Effectiveness of English Club as Free Voluntary Speaking Activity Strategy in Fostering Speaking Skill in Saudi Arabia Context. Online Submission, 2(1), 230-235.

Fikri, S. (2019). Students' Perception Toward Speaking Practice On English Week (Doctoral dissertation, Uin Ar Raniry).

Karunia, C. R. (2014). Students' Perception Toward Factors Causing Them Rarely Speak English of Sixht Semester Students of English Teacher Education Depatment at state Islamic University Sunan Ampel Surabaya (Doctoral dissertation, UIN Sunan Ampel).

Nahdah, F. S. (2019). Students' Perception Toward English club as an Extracurricular Activity in Speaking Practice of the Eleventh Grade Students in SMAN 1 Ngaglik (Doctoral dissertation,Universitas Ahmad Dahlan).

Nurhayati, F. Z., \& Fithriyah, N. H. M. P. (2019). The Implementation of English Club Pro- 
gram in Teaching Speaking Skill at MAN 1

Sragen in The Academic Year 2018/2019 (Doctoral dissertation, IAIN SURAKARTA).

Melviza, Z., Ys, S. B., \& Erdiana, N. (2017). Students' perception toward English club activities. Research in English and Education Journal, 2(2), 101-109.

Yuliandasari, A., \& Kusriandi, W. (2018). Students' Perception on English Club Extracurricular in Speaking Practices at Madrasah. Academic Journal Perspective: Education, Language, and Literature, 3(2), 305-315.

Zulhermindra, Z. (2019). Promoting English Club as an Extracurricular Activity for Young Learners: Suggested Procedure. Proceding IAN Batusangkar, 3(1), 389-400. 